\title{
SKRINING FITOKIMIA DAN PENETAPAN KANDUNGAN TOTAL FENOLIK EKSTRAK DAUN TUMBUHAN SAPU-SAPU (Baeckea frutescens L.)
}

\section{PHYTOCHEMICAL SCREENING AND DETERMINATION OF TOTAL PHENOLIC CONTENT OF PLANT LEAF EXTRACTS SAPU-SAPU (Baeckea frutescens L.)}

\author{
Dewi Septia Ningsih' ${ }^{1)}$, Henri $^{1{ }^{* *}}$, Occa Roanisca ${ }^{2)}$, Robby Gus Mahardika ${ }^{2)}$
}

\author{
Diterima : 13 Agustus 2020 \\ Disetujui : 29 Agustus 2020
}

\begin{tabular}{l} 
Afiliasi Penulis: \\
1) Program Studi Biologi, \\
Universitas Bangka Belitung, \\
Bangka Belitung, Indonesia \\
2) Program Studi Kimia, \\
Universitas Bangka Belitung, \\
Bangka Belitung, Indonesia \\
Alamat Korespondensi: \\
* biology.henry@ gmail.com \\
\hline
\end{tabular}

\section{Cara Sitasi:}

Ningsih, DS, Henri, O. Roanisca, \& RG. Mahardika. 2020. Skrining fitokimia dan penetapan kandungan total fenolik ekstrak daun tumbuhan Sapu-Sapu (Baeckea frutescens L.). Journal of Tropical Biology 8 (3): 178185.

\section{ABSTRAK}

Tumbuhan sapu-sapu (Baeckea frutescens L.) merupakan salah satu jenis keanekaragaman hayati yang tumbuh dan persebarannya cukup banyak di Indonesia. B. frutescens $L$ diketahui memiliki senyawa metabolit sekunder aktif yang dapat dimanfaatkan sebagai obat, antibakteri, dan antioksidan. Penelitian ini dilakukan untuk menganalisis kandungan senyawa metabolit sekunder yang terdapat pada B. frutescens L. Metode yang digunakan adalah ekstraksi dilanjutkan dengan pengujian fitokimia kualitatif yang terdiri dari tujuh pengujian yakni uji fenol, tanin, flavonoid, saponin, alkaloid, steroid dan terpenoid serta pengujian kuantitatif yakni pengujian total fenolik ekstrak B. frutescens L. Hasil penelitian menunjukkan bahwa didapatkan persentase bobot rendemen ekstrak daun B. frutescens L. sebesar ekstrak n-heksan 5,39\%, ekstrak etil asetat 14,54\% dan ekstrak etanol yakni 19,81\%. Hasil pengujian fitokimia kualitatif menujukkan senyawa fitokimia yang terkandung di dalam tumbuhan B. frutescens L. yakni pada ekstrak n-heksan hanya terdapat senyawa steroid dan pada ekstrak etil asetat terdapat senyawa fenolik, tanin, flavonoid, dan alkaloid. Selain itu, pada ekstrak etanol terdapat senyawa fenolik, tanin, flavonoid, saponin, steroid, dan alkaloid. Pengujian total fenolik ekstrak daun tumbuhan B. frutescens L. untuk pelarut etil asetat yakni 0,24\% dan pelarut etanol yakni sebesar 0,14\% dihitung terhadap senyawa fenol asam galat. Hasil penelitian ini diharapkan dapat menjadi informasi untuk penelitian lebih lanjut mengenai pemanfaatan kandungan metabolit sekunder B. frutescens $L$.

Kata kunci: Baeckea frutescens L., skrining fitokimia, total fenolik

\section{ABSTRACT}

Sapu-sapu plant (Baeckea frutescens L.) is a type of biodiversity that grows and spreads quite a lot in Indonesia. B. frutescens $L$. is known to have active secondary metabolite compounds that can be used as a medicine, antibacterial, and antioxidant. This study was conducted to analyze the content of secondary metabolites found in B. frutescens $L$. The method used was extraction, followed by qualitative phytochemical testing consisting of seven tests, namely phenol, tannin, flavonoid, saponins, alkaloids, steroids, and terpenoids as well as testing. quantitative, namely the total phenolic test of B. frutescens L. extract. The results showed that the yield weight percentage of B. frutescens $L$. leaf extract was $5.39 \%$ n-hexane extract, $14.54 \%$ ethyl acetate extract, and 19.81 ethanol extract. \%. The results of qualitative phytochemical testing showed that the phytochemical compounds contained in the B. frutescens L. plant, namely the n-hexane extract contained only steroid compounds and ethyl acetate extract contained phenolic compounds, tannins, flavonoids, and alkaloids. Besides, the ethanol extract contains phenolic compounds, tannins, flavonoids, saponins, steroids, and alkaloids. The total phenolic test of the plant leaf extract of B. frutescens L. for ethyl 
acetate solvent was $0.24 \%$ and ethanol solvent, namely $0.14 \%$, was calculated for the phenol compound gallic acid. The results of this study are expected to provide information for further research on the utilization of the secondary metabolites content of $B$. frutescens $L$.

Keywords: Baeckea frutescens L., phenolic compound, secondary metabolites

\section{PENDAHULUAN}

Tumbuhan menghasilkan senyawa metabolit sekunder yang biasanya dimanfaatkan dalam industri obat-obatan. Alkaloid, flavonoid, saponin, steroid, dan tanin merupakan beberapa golongan senyawa kimia yang merupakan hasil metabolisme sekunder pada tumbuhan [1]. Konstituen kimiawi yang berbeda pada tanaman obat memiliki aktivitas biologis yang dapat meningkatkan kesehatan manusia melalui industri farmasi dan makanan, namun juga mewakili nilai penting dalam industri parfum, agrokimia, kosmetik [2]. Metabolit sekunder tumbuhan merupakan kelompok senyawa yang sangat besar dengan berat molekul kecil, yang difungsikan untuk tujuan perlindungan terhadap serangga, mikroba, dan herbivor. Selain itu, berperan dalam upaya beradaptasi dengan kondisi lingkungan yang merugikan. Metabolit sekunder tumbuhan di alam ini memainkan peran penting sebagai antibakteri, antijamur, antivirus, herbisida, dan insektisida [3].

Tumbuhan memiliki kemampuan untuk mensintesis berbagai metabolit sekunder beragam struktur dan kerangka karbon yng begitu kompleks. Tumbuhan tingkat tinggi diketahui mulai dimanfaatkan sekitar 14-28\% ekstrak sebagai obat-obatan dan $74 \%$ diketahui memiliki fungsional lainnya atau penggunaan sebagai obat tradisional [4]. Pemanfaatan tumbuhan sebagai obat sudah banyak dilakukan akan tetapi ada sekitar 250.000 spesies tumbuhan tertinggi di dunia, hanya 5$15 \%$ yang telah diperiksa senyawa bioaktifnya [5].

Tumbuhan sapu-sapu (Baeckea frutescens L.) merupakan salah satu jenis keanekaragaman hayati yang tumbuh dan persebarannya cukup banyak di Indonesia. $B$. frutescens L. memiliki nama daerah yang berbeda seperti ujung atap atau jungrahab. Tumbuhan ini merupakan tumbuhan dari famili Myrtaceae yang persebarannya cukup luas. Tumbuhan ini banyak ditemukan di daerah berpasir seperti pantai dan kadang terdapat pada dataran tinggi dengan kondisi tanah yang kurang subur. B. frutescens $\mathrm{L}$. merupakan tumbuhan semak-semak berkayu menyerupai pohon cemara yang memiliki aroma khas [6]. Sehingga tumbuhan ini digolongkan sebagai tumbuhan aromatik karena aromanya yang khas. Selain itu, memiliki karakter secara morfologi berdaun halus, berbentuk sepeti jarum kecil, dan merupakan tumbuhan perdu [7].

Tumbuhan B. frutescens L. merupakan salah satu jenis tumbuhan yang memiliki senyawa metabolit sekunder aktif. Senyawasenyawa turunan dari golongan flavanoid salah satunya yakni flavonon [8]. Namun, sejauh ini skrining fitokimia $B$. frutescens $\mathrm{L}$. masih belum cukup banyak dilakukan terutama di Bangka Belitung. Skrining fitokimia merupakan metode sederhana yang sering digunakan dan merupakan tahap awal untuk mengidentifikasi atau mengetahui kandungan dan golongan senyawa yang terdapat pada simplisia uji [1]. Perlunya dilakukan penelitian untuk mengetahui kandungan senyawa metabolit sekunder yang terdapat pada $B$. frutescens L. sehingga diharapkan dapat menambah data kandungan fitokimia $B$. frutescens L. yang ada di Bangka Belitung dan dapat menjadi informasi untuk penelitian lebih lanjut mengenai pemanfaatan kandungan metabolit sekundernya.

\section{METODE PENELITIAN}

Pengambilan sampel. Pengambilan sampel penelitian dilakukan pada kawasan Hutan Kerangas Area Pantai Lintas Timur Bangka Belitung. Sampel yang diambil berupa seluruh bagian daun $B$. frutescens $\mathrm{L}$. dan selanjutnya dicuci menggunakan air mengalir serta ditiriskan. Sampel dikeringkan dengan menggunakan oven pada suhu $50^{\circ} \mathrm{C}$ selama $2 \mathrm{x}$ 24 jam, kemudian sampel tersebut dihaluskan dengan menggunakan blender.

Ekstraksi sampel. Simplisia dari daun $B$. frutescens L.yang digunakan sebanyak $300 \mathrm{~g}$ kemudian dilakukan maserasi dengan metode maserasi bertingkat menggunakan pelarut $n$ heksan, etil asetat dan etanol (teknis). Metode maserasi dilakukan dengan merendam simplisia dalam suatu pelarut. Remaserasi dilakukan selama 1 x 24 jam sambil sesekali 
diaduk, kemudian maserat dipisahkan dari residu menggunakan corong Buchner yang selanjutnya diuapkan dengan rotary evaporator pada suhu $50^{\circ} \mathrm{C}$. Persentase bobot rendemen ekstrak dihitung mengacu pada rumus:

$\%$ Rendemen $=\frac{\text { Bobot ekstrak kental }(\mathrm{g})}{\text { Bobot sebelum dieksrtak (g) }} \times 100 \%$

\section{Skrining Fitokimia}

Uji fenol. Uji fenol dilakukan dengan sebanyak 0,5 g ekstrak ditambahkan 3-4 tetes $\mathrm{FeCl}_{3}$ terjadinya perubahan warna hitam kebiruan hingga hitam pekat menunjukkan adanya kandungan fenol [9].

Uji tanin. Uji tanin dilakukan dengan sebanyak 0,5 gram ekstrak ditambahkan dengan $10 \mathrm{~mL}$ air panas, dan ditetesi dengan $\mathrm{FeCl}_{3} 1 \%$ terbentuknya warna hijau kehitaman menunjukkan adanya kandungan tanin [10].

Uji flavonoid. Uji flavonoid dilakukan dengan sebanyak $0,5 \mathrm{~g}$ ekstrak dan ditambahkan etanol sebanyak $5 \mathrm{~mL}$, setelah itu dilakukan pemanasan \pm 5 menit dan ditambahkan $\mathrm{HCl}$ pekat sebanyak 10 tetes dan 0,2 gram serbuk magnesium. Sehingga terbentuknya warna hitam kemerahan, kuning atau jingga menunjukkan hasil positif flavonoid [11].

Uji saponin. Sebanyak 0,5 gram ekstrak dimasukkan ke dalam tabung reaksi kemudian ditambahkan dengan akuades yang telah dipanaskan sebelumnya sebanyak $10 \mathrm{~mL}$. Campuran dikocok kuat kurang lebih selama 1 menit. Selanjutnya didiamkan selama 10 menit dan diamati buih atau busa yang terbentuk yang menandakan hasil positif saponin [11].

Uji alkaloid. Uji alkaloid dilakukan dengan sebanyak 0,5 g ekstrak kemudian ditambahkan kloroform sebanyak $2 \mathrm{ml}$, amonia sebanyak 10 $\mathrm{ml}$ serta 10 tetes $\mathrm{H}_{2} \mathrm{SO}_{4}$. Campuran dikocok dan dibiarkan hingga membentuk dua lapisan. Lapisan $\mathrm{H}_{2} \mathrm{SO}_{4}$ yang terbentuk dipindahkan dalam tiga tabung reaksi dengan volume masing-masing tabung 2,5 ml. Ketiga larutan diuji dengan pereaksi Mayer, Dragendorf, dan Wagner. Hasil positif pereaksi Mayer ditandai dengan terbentuknya endapan putih, pada pereaksi Dragendorf terdapat endapan berwarna merah atau jingga sedangkan untuk pereaksi Wagner terdapat endapan berwarna coklat [10].

Uji steroid dan terpenoid. Sebanyak $0,5 \mathrm{~g}$ ekstrak dimasukkan ke dalam tabung reaksi yang kemudian ditambahkan $\mathrm{H}_{2} \mathrm{SO}_{4}$ pekat sebanyak $2 \mathrm{ml}$. Larutan dikocok perlahan dan dibiarkan beberapa menit. Warna biru sampai hijau menunjukkan hasil positif uji steroid sedangkan untuk warna merah kecoklatan sampai ungu menunjukkan hasil positif uji terpenoid [12].

Uji kuantitatif fenol. Ekstrak sebanyak 10 mg dilarutkan dengan $10 \mathrm{~mL}$ metanol kemudian diambil sebanyak 0,5 $\mathrm{mL}$ dimasukkan ke dalam tabung reaksi yang kemudian ditambahkan dengan $0,5 \mathrm{~mL}$ reagen Folin-Ciocalteau dan 2,5 mL larutan $\mathrm{Na}_{2} \mathrm{CO}_{3}$ $7,5 \%$. Tabung reaksi divortex selama 1 menit dan diinkubasi pada suhu ruang selama 15 menit. Absorbansi diukur dengan spektrofotometri UV-Vis pada panjang gelombang maksimum $756 \mathrm{~nm}$. Kadar total fenolik dinyatakan dalam mg Equivalen Asam Gallat/g [13].

\section{HASIL DAN PEMBAHASAN}

Rendemen Baeckea frutescens L. Metode maserasi yang digunakan memiliki keuntungan yaitu peralatan dan prosedur yang digunakan sangat sederhana, pelaksanaannya mudah karena tidak memerlukan perlakuan khusus yaitu hanya dengan merendam sampel dalam pelarut pengekstraksi sambil sesekali diaduk serta metode ini dapat menghindari rusaknya senyawa yang bersifat termolabil. Pemilihan metode ekstraksi sangat mempengaruhi rendemen yang dihasilkan, rendemen ekstrak daun tumbuhan $B$. frutescens $\mathrm{L}$. yakni sebesar; ekstrak $n$-heksan 5,39\%, ekstrak etil asetat $14,54 \%$ dan ekstrak etanol yakni 19,81\% (Tabel 1).

Rendemen hasil ekstraksi dengan menggunakan tiga jenis pelarut yang berbeda menghasilkan persentase rendemen yang berbeda. Banyaknya hasil rendemen dipengaruhi oleh sifat kelarutan komponen bioaktifnya. Hasil persentase rendemen daun tumbuhan $B$. frutescens $\mathrm{L}$. tertinggi didapatkan pada penggunaan pelarut etanol, sehingga kemungkinan besar senyawa bioaktif yang terdapat pada ekstrak daun $B$. frutescens $\mathrm{L}$. lebih bersifat polar. Etanol merupakan pelarut ideal yang sering digunakan karena merupakan pelarut pengekstraksi salah satu yang mampu mengekstrak senyawa fitokimia dalam jumlah yang lebih banyak dan hampir untuk semua senyawa dengan berat molekul rendah seperti saponin dan flavonoid [14]. 
Tabel 1. Hasil rendemen $B$. frutescens $\mathrm{L}$.

\begin{tabular}{ccc}
\hline Pelarut & Ekstrak $(\mathrm{g})$ & Rendemen $(\%)$ \\
\hline$n$-heksan & 16,17 & 5,39 \\
Etil asetat & 43,62 & 14,54 \\
Etanol & 59,45 & 19,81 \\
\hline
\end{tabular}

Hasil penelitian menunjukkan bahwa pelarut yang berbeda menghasilkan hasil rendemen yang bervariasi. Hal ini dikarenakan perbedaan polaritas pelarut ekstraksi dapat menyebabkan variasi yang luas pada kadar senyawa bioaktif dalam ekstrak. Hasil ekstraksi yang lebih tinggi diamati pada ekstrak etanol, dibandingkan dengan ekstrak etil asetat dan $n$-heksan, yang menunjukkan bahwa efisiensi ekstraksi lebih menyukai pelarut yang sangat polar. Hal ini dapat dikaitkan dengan kelarutan yang lebih tinggi dari senyawa ini dalam etanol daripada pelarut lain yang diuji [15]. Pelarut ekstraksi berpengaruh pada hasil ekstraksi dan kandungan senyawa bioaktif, sehingga secara signifikan memengaruhi aktivitas biologis ekstrak [16].

Pelarut etanol memiliki berat molekul rendah sehingga mampu membuat ikatan hidrogen bercampur dan larut dengan $\mathrm{H}_{2} \mathrm{O}$ sampai dengan kelarutan yang tidak terhingga. Etanol memiliki gugus polar yang sangat kuat dikarenakan terdapat gugus hidroksil $(-\mathrm{OH})$ dengan nilai keelektronegatifan oksigen yang sangat tinggi dan mampu mengikat hidrogen sehingga dapat berikatan dengan molekul polar dan molekul ion. Hasil rendemen yang menggunakan pelarut etil asetat lebih kecil apabila dibandingkan pelarut etanol dikarenakan adanya gugus metoksi yang tidak begitu kuat, sehingga menyebabkan terbentuknya ikatan hidrogen. Nilai rendemen terkecil didapatkan pada pelarut $n$-heksana, hal ini menunjukkan bahwa senyawa bioaktif yang bersifat non polar pada sampel daun $B$. frutescens L. jumlahnya sedikit [17].

Senyawa fitokimia ekstrak $\boldsymbol{n}$-heksan, etil asetat, dan etanol. Uji fitokimia dilakukan untuk mengetahui golongan senyawa yang terkandung pada daun tumbuhan sapu-sapu $(B$. frutescens L). Berdasarkan hasil penelitian yang telah dilakukan diketahui bahwa golongan senyawa fitokimia (Tabel 2) yang terkandung di dalam tumbuhan $B$. frutescens $\mathrm{L}$ yakni; pada ekstrak $n$-heksan hanya terdapat steroid, pada ekstrak etil asetat terdapat fenolik, tanin, flavonoid, dan alkaloid, sedangkan pada ekstrak etanol terdapat fenolik, tanin, flavonoid, saponin, steroid, dan alkaloid.

Hasil yang sama ditunjukkan pada penelitian sebelumnya bahwa senyawa fitokimia yang terkandung dalam ekstrak daun $B$. frutescens L. yakni fenolik, flavonoid, dan glikosida [18]. Pengujian pada ekstrak daun $B$. frutescens L. yang menggunakan pelarut etil asetat dan pelarut etanol diketahui terdapat senyawa fenolik. Senyawa fenolik ditunjukkan terjadinya perubahan warna hitam pada sampel uji namun tidak terlalu pekat setelah ditambahkan dengan $\mathrm{FeCl}_{3} 1 \%$. Senyawa fenolik dinyatakan positif apabila terdapat perubahan warna hitam kebiruan hingga hitam pekat pada saat penambahan $\mathrm{FeCl}_{3} 1 \%$ [19] dan $\mathrm{FeCl}_{3}$ dapat bereaksi dengan gugus $-\mathrm{OH}$ aromatis [20].

Tabel 2. Hasil uji skrining B. frutescens L.

\begin{tabular}{lccc}
\hline \multirow{2}{*}{ Uji Fitokimia } & \multicolumn{3}{c}{ Hasil } \\
\cline { 2 - 4 } & $\begin{array}{c}n- \\
\text { heksan }\end{array}$ & $\begin{array}{c}\text { etil } \\
\text { asetat }\end{array}$ & etanol \\
\hline Fenolik & - & + & + \\
Tanin & - & + & + \\
Flavonoid & - & + & + \\
Saponin & - & - & - \\
Steroid & + & - & - \\
Terpenoid & - & + & + \\
Alkaloid & & & - \\
$\quad$ Dragendorf & - & - & - \\
Mayer & + & - & - \\
Wagner & - & + &
\end{tabular}

Ket: (+) uji dinyatakan mengandung senyawa fitokimia (-) uji dinyatakan tidak mengandung senyawa fitokimia

Hasil pengujian pada ekstrak daun $B$. frutescens L. menggunakan pelarut etil asetat dan etanol menunjukkan terdapatnya senyawa tanin. Senyawa tanin dibuktikan dengan terjadinya perubahan warna ekstrak yakni hijau kehitaman. Hasil dinyatakan positif apabila terjadi perubahan warna hijau kehitaman pada saat penambahan $\mathrm{FeCl}_{3} 1 \%$ [11]. Hal ini karena penambahan $\mathrm{FeCl}_{3}$ pada tanin akan dapat membentuk senyawa kompleks dengan ion $\mathrm{Fe}^{3+}[21]$.

Senyawa flavonoid dinyatakan positif apabila pada saat pengujian terjadi perubahan warna hitam kemerahan, kuning, atau jingga [11]. Hasil penelitian menunjukkan bahwa ekstrak etil asetat dan etanol pada daun $B$. frutescens $\mathrm{L}$. mengandung senyawa flavonoid, hal tersebut dibuktikan dengan adanya perubahan warna hitam kemerahan pada ekstrak yang diuji. Penambahan $\mathrm{HCl}$ dan bubuk magnesium, perubahan warna ekstrak 
menjadi hitam kemerahan menunjukkan hasil positif flovonoid [22]. Tujuan penambahan beberapa tetes larutan $\mathrm{HCl}$ dan bubuk $\mathrm{Mg}$ adalah untuk mereduksi inti benzopiron yang terdapat dalam struktur flavonoid sehingga terbentuk garam flavilium berwarna merah atau jingga [21].

Warna biru sampai hijau menunjukkan hasil positif senyawa steroid, sedangkan untuk warna merah kecoklatan sampai ungu menunjukkan hasil positif uji terpenoid [12]. Berdasarkan hasil pengujian pada daun $B$. frutescens $\mathrm{L}$. yang mengandung senyawa steroid pada ekstrak etil asetat dan etanol. Hal ini ditunjukkan dengan terjadinya perubahan warna ekstrak menjadi biru sampai hijau, sedangkan untuk pengujian terpenoid menunjukkan hasil positif pada ekstrak etil asetat dan etanol daun $B$. frutescens $\mathrm{L}$. Perubahan warna yang terjadi diakibatkan adanya senyawa terpenoid dan steroid, sehingga terjadi perubahan warna ungu dan biru-hijau dan bereaksi dengan $\mathrm{H}_{2} \mathrm{SO}_{4}$. Perbedaan warna yang dihasilkan disebabkan oleh adanya perbedaan gugus pada atom C-4 [20].

Pengujian fitokimia senyawa alkaloid dilakukan dengan menggunakan tiga pereaksi yakni pereaksi Dragendorff, pereaksi Mayer, dan pereaksi Wagner. Pengujian menggunakan ketiga pereaksi ini untuk mengetahui perubahan warna setelah dilakukannya pengujian sifat kelarutannya. Hasil pengujian yang telah dilakukan menunjukkan ekstrak nheksan daun $B$. frutescens $L$. mengandung senyawa alkaloid. Hasil positif ditunjukkan pada pegujian dengan menggunakan pereaksi Mayer yakni terdapat endapan berwarna putih. Pengujian positif alkaloid menggunakan pereaksi Mayer ditandai dengan terbentuknya endapan putih pada larutan [11]. Pengujian senyawa alkaloid dengan pereaksi Mayer, menunjukkan hasil positif dengan terbentuknya endapan berwarna putih. Pada identifikasi alkaloid dengan pereaksi Mayer, nitrogen dalam alkaloid diperkirakan bereaksi dengan ion logam kalium $\left(\mathrm{K}^{+}\right)$dari Kalium tetraiodomerkurat (II) menghasilkan kompleks pengendapan kalium-alkaloid. Alkaloid diketahui terdiri dari atom nitrogen yang memiliki elektron pasangan bebas. Elektron pasangan elektron bebas diperiksa untuk membentuk ikatan koordinat kovalen dengan ion logam [23].

Hasil positif pegujian alkaloid juga didapatkan pada ekstrak etil asetat daun $B$. frutescens $\mathrm{L}$. dengan menggunakan pereaksi
Wagner yakni terdapat endapan berwarna coklat. Pengujian dengan pereaksi Wagner dinayatakan positif dengan ditandai terbentukanya endapat berwarna coklat pada larutan [11]. Endapan yang terdapat pada uji alkaloid dengan menggunakan pereaksi Wagner adalah kalium-alkaloid. Iodin yang bereaksi dengan ion $\mathrm{I}^{-}$dari kalium iodida pada pembuatan pereaksi Wagner menghasilkan ion $\mathrm{I}^{3-}$ yang berwarna coklat. Endapan yang dihasilkan diduga merupakan ion logam $\mathrm{K}^{+}$ yang membentuk suatu ikatan kovalen dengan nitrogen pada alkaloid sehingga terjadi pembentukan secara kompleks kalium-alkaloid yang dapat mengendap [10].

Hasil di atas menunjukkan senyawa metabolit sekunder yang dihasilkan dipengaruhi oleh jenis pelarut yang digunakan pada saat proses ekstraksi. Ekstraksi dapat dilakukan berdasarkan sifat kepolarannya pada suatu zat dalam pelarut saat dilakukan proses ekstraksi. Pada umumnya pelaut polar seperti air, metanol, etanol, butanol, asam asetat, asam format dan lainnya dapat melarutkan senyawa yang bersifat polar. Senyawa non polar tentu juga hanya akan larut menggunakan pelarut yang bersifat non-polar seperti eter, kloroform, dan heksan. Jenis pelarut dan kualitas pelarut menentukan suatu keberhasilan proses dalam ekstraksi. Pelarut yang digunakan harus mampu melarutkan suatu zat yang dibutuhkan atau diinginkan, mempunyai titik yang rendah, murah, tidak toksik dan tidak mudah terbakar [24]. Senyawa-senyawa yang bersifat polar merupakan senyawa golongan fenol (fenolik, flavonoid, tanin, saponin, dan lignan), sedangkan alkaloid dan steroid merupakan senyawa yang bersifat non polar [17].

Kadar total fenolik. Berdasarkan hasil pengukuran absorbansi masing-masing konsentrasi larutan standar asam galat menggunakan spektrofotometer UV-Vis, diperoleh nilai absorbansi yang diolah dengan menggunakan Microsoft Excel, didapatkan kurva kalibrasi larutan standar asam galat berupa grafik kurva konsentrasi versus absorbansi. Kurva persamaan garis linear untuk penetapan kadar total fenolik pada ekstrak etil asetat dan etanol daun $B$. frutescens L. seperti pada Gambar 1.

Berdasarkan grafik yang didapat diketahui bahwa kurva baku asam galat ditetapkan dengan menggunakan persamaan regresi linier, yang menyatakan hubungan antara konsentrasi asam galat dinyatakan sebagai $x$ dan absorbansi asam galat dengan pereaksi FolinCiocalteu dinyatakan sebagai y. Pada 
penelitian ini diperoleh persamaan kurva baku asam galat pada konsentrasi $0,0,2$ dan $0,5 \mathrm{ppm}$ yaitu $y=6,82221 x+0,7048$ dengan $r^{2}=0,978$.

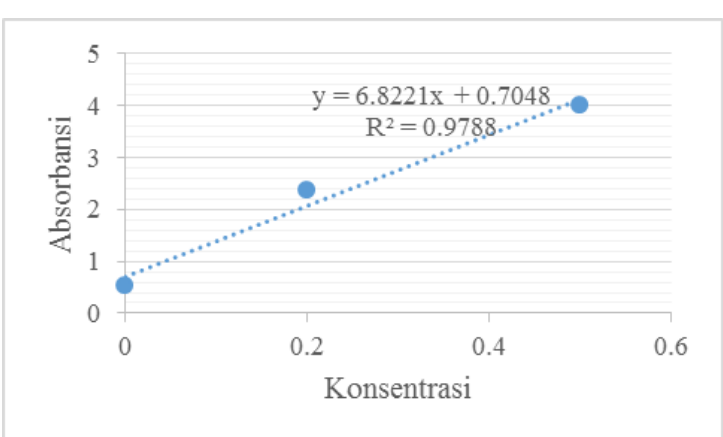

Gambar 1. Kurva kalibrasi asam galat

Berdasarkan hasil perhitungan dengan persamaan regresi larutan standar diperoleh kadar total fenolik ekstrak daun B. frutescens $\mathrm{L}$ untuk pelarut etil asetat yakni $0,24 \%$ dan pelarut etanol yakni sebesar $0,14 \%$ dihitung terhadap senyawa fenol asam galat (Tabel 3).

Berdasarkan hasil tersebut diketahui bahwa senyawa fenolik pada ekstrak etil asetat lebih besar dibandingkan dengan ekstrak etanol. Hal ini dikarenakan berat molekul fenolik yang mendekati berat molekul etil asetat sehingga lebih mudah pelarut etil asetat untuk mengekstrak senyawa fenolik. Tingginya total polifenol pada pelarut etil asetat diduga adanya golongan polifenol yang memiliki berat molekul yang sama dengan pelarut etil asetat seperti tanin dan flavanol [25]. Senyawa fenolik umumnya lebih mudah diekstrak oleh pelarut organik yang bersifat semi polar [26].

Tabel 3. Hasil pengukuran kadar total fenolik

\begin{tabular}{cccc}
\hline Sampel & Absorbansi & $\begin{array}{c}\text { Total } \\
\text { fenolik } \\
\text { (mgGAE/g) }\end{array}$ & $\begin{array}{c}\text { Total } \\
\text { fenolik } \\
(\boldsymbol{\%})\end{array}$ \\
\hline EEADS & 0,535 & $\begin{array}{c}0,0024 \\
\mathrm{mgGAE} / \mathrm{g}\end{array}$ & $0,24 \%$ \\
EEDS & 0,804 & $\begin{array}{c}0,0014 \\
\text { mgGAE/g }\end{array}$ & $0,14 \%$ \\
\multicolumn{4}{c}{ Ket: EEADS: Ekstrak Etil Asetat Daun Sapu-Sapu } \\
EADS: Ekstrak Etanol Daun Sapu-Sapu
\end{tabular}

Asam galat digunakan sebagai larutan standar dikarenakan sebagai salah satu fenol alami dan stabil. Asam galat merupakan senyawa fenolik turunan asam hidroksibenzoat yang merupakan golongan asam fenol sederhana [13]. Asam galat sebagai senyawa tripenol dengan berat molekul rendah yang terjadi secara alami telah banyak digunakan sebagai aktivitas biologis dan farmakologis yang beragam, seperti antioksidan [27].
Pengujian dengan menggunakan standar asam galat yang direaksikan dengan reagen Folin-Ciocalteu akan menghasilkan warna kuning yang menandakan bahwa ekstrak yang diuji mengandung fenol, yang kemudian ditambahkan dengan larutan $\mathrm{Na}_{2} \mathrm{CO}_{3}$ menghasilkan warna biru. Penambahan $\mathrm{Na}_{2} \mathrm{CO}_{3}$ bertujuan agar fenolik dapat beraksi dengan reagen Folin-Ciocalteu. Senyawa fenolik hanya akan bereaksi dengan reagen Folin-Ciocalteu dalam suasana basa agar terjadinya suatu disosiasi proton antara senyawa fenolik menjadi ion fenolat dengan adanya penambahan larutan $\mathrm{Na}_{2} \mathrm{CO}_{3}$ [28].

\section{KESIMPULAN}

Senyawa fitokimia yang terkandung dalam ekstrak daun Baeckea frutescens L. yakni steroid dan alkaloid pada ekstrak n-heksan. Senyawa fenolik, flavonoid, tanin, terpenoid dan alkaloid pada ekstrak etil asetat, sedangkan senyawa fenolik, flavonoid, terpenoid dan tanin pada ekstrak etanol. Hasil pengujian total fenolik ekstrak daun $B$. frutescens $L$. diketahui hasilnya pada pelarut etil asetat sebesar $0,24 \%$ dan pelarut etanol sebesar $0,14 \%$ dihitung terhadap senyawa fenol asam galat. Penelitian ini dapat menjadi dasar uji lanjut mengenai identifikasi kandungan fitokimia secara kuantitatif, uji aktivitas antibakteri, antimalaria maupun antioksidan.

\section{UCAPAN TERIMA KASIH}

Terima kasih sebesar-besarnya kepada Kepala Laboratorium Biologi dan Kepala Laboratorium MIPA Dasar Universitas Bangka Belitung atas segala fasilitas laboratorium yang digunakan selama penelitian ini berlangsung.

\section{DAFTAR PUSTAKA}

[1] Dewatisari WF, Rumiyanti L, Rakhmawati I (2018) Rendemen dan skrining fitokimia pada ekstrak daun Sanseviera sp. Jurnal Penelitian Pertanian Terapan 17: 197-202.

[2] Hassan BAR (2010) Medicinal plants (Importance and Uses). Pharmaceutica Analytica Acta 3: 4172.

[3] Miguel MG (2010) Antioxidant and antiinflammatory activities of essential oils: A short review. Molecules 15: 9252-9287.

[4] Cavoski I, Caboni P, Miano T (2011) Natural pesticides and future perspectives. In Margarita Stoytcheva (Eds.), Pesticides 
in the Modern World - Pesticides Use and Management. Rijeka: InTech Europe, pp 169-190.

[5] Juárez P (2014) Plant-derived anticancer agents: a promising treatment for bone metastasis. BoneKEy Reports 3: 1-8.

[6] Supandi M, Wibowo MA, Zaharah TA (2019) Karakterisasi minyak atsiri daun Ujung Atap (Baeckea Frustescens L) dari hutan Desa Sungai Nanjung Kabupaten Ketapang Kalbar. Indonesian Journal of Pure and Applied Chemistry 2: 74-83.

[7] Murningsih T (2009) Studi fitokimia Baeckea frutescens L: Pengaruh faktor lingkungan terhadap komposisi kimia minyak atsiri. Berita Biologi 9: 569-576.

[8] Murningsih T (2010) Aktivitas antioksidan dan analisis kimia ekstrak daun Jungrahab (Baeckea frutescens L.). Berita Biologi 10: 129-134.

[9] Azizah Z, Wati SW (2018) Skrining fitokimia dan penetapan kadar flavonoid total ekstrak etanol daun Pare (Momordica charantia L.). Jurnal Farmasi Higea 10: 163-172.

[10] Marliana SD, Suryanti V, Suyono (2005) Skrining fitokimia dan analisis kromatografi lapis tipis komponen kimia buah labu siam (Sechium edule Jacq. Swartz.) dalam ekstrak etanol. Biofarmasi 3: 26-31.

[11] Tarukbua YSF, Queljoe ED, Bodhi W (2018) Skrining fitokimia dan uji toksisitas ekstrak etanol daun Brotowali (Tinospora crispa (L.) Hook F. \& T) dengan metode Brine Shrimp Lethality Test (BSLT). PHARMACON Jurnal Ilmiah Farmasi-UNSRAT 7: 330-337.

[12] Kursia S, Lebang JS, Taebe B, Burhan A, Rahim WO, Nursamsiar (2016) Uji aktivitas antibakteri ekstrak etilasetat daun Sirih Hijau (Piper betle L.) terhadap bakteri Staphylococcus epidermidis. Indonesian Journal of Pharmaceutical Science and Technology 3: 72-77.

[13] Ahmad AR, Juwita J, Ratulangi SAD (2015) Penetapan kadar fenolik dan flavonoid total ekstrak metanol buah dan daun Patikala (Etlingera elatior (Jack) R.M.SM). Pharmaceutical Sciences and Research 2: 1-10.

[14] Arifianti L, Oktarina RD, Kusumawati I (2014) Pengaruh jenis pelarut pengekstraksi terhadap kadar sinensetin dalam ekstrak daun Orthosiphon stamineus Benth. E-Journal Planto Husada 2: 1-4.
[15] Do QD, Angkawijaya AE, Tran-Nguyen PL, Huynh LH, Soetaredjo FE, Ismadji S (2014) Effect of extraction solvent on total phenol content, total flavonoid content, and antioxidant activity of Limnophila aromatica. Journal of Food and Drug Analysis 22: 296-302.

[16] Ngo TV, Scarlett CJ, Bowyer MC, Ngo PD, Vuong QV (2017) Impact of different extraction solvents on bioactive compounds and antioxidant capacity from the root of Salacia chinensis L. Journal of Food Quality 1-8.

[17] Romadanu R, Hanggita S, Lestari S (2014) Pengujian aktivitas antioksidan ekstrak bunga Lotus (Nelubo nucifera). Jurnal FishtecH 3: 1-7.

[18] Razmavar S, Abdulla MA, Ismail SB, Hassandarvish P (2014) Antibacterial activity of leaf extracts of Baeckea frutescens against methicillin-resistant Staphylococcus aureus. BioMed Research International 1-5.

[19] Habibi AI, Firmansyah RA, Setyawati SM (2018) Skrining fitokimia ekstrak nheksan korteks batang Salam (Syzygium polyanthum). Indonesian Journal of Chemical Science 7: 1-4.

[20] Haryati N, Saleh C, Erwin (2015) Uji toksisitas dan aktivitas antibakteri ekstrak daun merah tanaman Pucuk Merah (Syzygium myrtifolium Walp.) terhadap bakteri Staphylococcus aureus dan Escherichia coli. Jurnal Kimia Mulawarman 13: 35-40.

[21] Ergina, Nuryanti S, Pursitasari ID (2014) Uji kualitatif senyawa metabolit sekunder pada daun Palado (Agave angustifolia) yang diekstraksi dengan pelarut air dan etanol. Jurnal Akademika Kimia 3: 165172.

[22] Rumagit HM, Runtuwene MRJ, Sudewi S, Kimia J, Manado FU (2015) Uji fitokimia dan uji aktivitas antioksidan dari ekstrak spons Lamellodysidea herbacea. PHARMACON: Jurnal Ilmiah FarmasiUNSRAT 4: 183-192.

[23] Parbuntari H, Prestica Y, Gunawan R, Nurman MN, Adella F (2018) Preliminary phytochemical screening (qualitative analysis) of cacao leaves (Theobroma cacao L.). EKSAKTA: Berkala Ilmiah Bidang MIPA 19: 40-45.

[24] Mukhriani (2014) Esktraksi pemisahan senyawa dan identifikasi senyawa aktif. Jurnal Kesehatan 7: 361-367.

[25] Nur A, Astawan M (2011) Kapasitas 
antioksidan bawang Dayak (Eleutherine palmifolia) dalam bentuk segar, simplisia dan keripik, pada pelarut nonpolar, semipolar dan polar. Skripsi. Institut Pertanian Bogor, Departemen Ilmu dan Teknologi Pangan.

[26] Yanuarti R, Nurjanah N, Anwar E, Hidayat T (2017) Profil fenolik dan aktivitas antioksidan dari ekstrak rumput laut Turbinaria conoides dan Eucheuma cottonii. JPHPI 20: 230-237.

[27] Badhani B, Sharma N, Kakkar R (2015) Gallic acid: A versatile antioxidant with promising therapeutic and industrial applications. RSC Advances. Royal Society of Chemistry 5: 27540-27557.

[28] Alfian R, Susanti H (2012) Penetapan kadar fenolik total ekstrak metanol kelopak bunga Rosella Merah (Hibiscus sabdariffa Linn) dengan variasi tempat tumbuh secara spektofotometri. Jurnal Ilmiah Kefarmasian 2: 73-80. 